\title{
STRATEGI PENGAJARAN IMMERSION: MENINGKATKAN KETERAMPILAN BERBAHASA INGGRIS REMAJA MESJID DESA SEMANGAT DALAM, KECAMATAN ALALAK KABUPATEN BARITO KUALA
}

\author{
Hengki dan Ratna \\ Fakultas Keguruan dan Ilmu Pendidikan, Universitas Islam Kalimantan \\ E-mail : hengkisakkai@yahoo.co.id, ratnabugisbone@yahoo.co.id
}

\begin{abstract}
ABSTRAK
Strategi dan model pengajaran immersion merupakan model pembelajaran bahasa Inggris yang banyak dipraktekan di negara-negara maju untuk mempercepat penguasaan bahasa Inggris siswa dan juga mahasiswa. Dalam rangka mempercepat kemampuan berbicara bahasa Inggris para generasi mudah utamanya remaja mesjid sebagai generasi masa depan bangsa perlu mendapat fasilitas dan motivasi dari orang tertentu seperti pengurus mesjid dan tokoh masyarakat dengan mendatangkan para guru atau Dosen yang mampu mengajar keterampilan berbicara dengan menggunakan strategi dan model pembelajaran yang tepat, atraktif, menarik dan disenangi oleh para siswa. Strategi dan model pengajaran yang digunakan oleh para guru atau Dosen bahasa Inggris memiliki peran yang sangat penting untuk meningkatkan ketertarikan dan kecintaan pelajar berlatih keterampilan berbahasa Inggris.Peningkatan keterampilan berbicara bahasa asing seperti bahasa Inggris melalui kegiatan formal terbukti masih sangat jauh dari harapan, begitu pula kegiatan nonformal seperti di lembaga kursus juga belum memberikan hasil yang memuaskan secara umum karena masih sangat terbatas pelajar yang bisa mengikuti kegiatan tersebut disebabkan oleh beberapa faktor, yaitu:faktor ekonomi, faktor kesibukan dengan pelajaran lain, dan faktor motivasi belajar bahasa asing yang tergolong rendah. Factor-faktor penghambat tersebut juga dialami oleh para remaja mesjid yang ada di Desa Semangat Dalam, Kecamatan Alalak Kabupaten Barito Kuala. Remaja mesjid tersebut perlu mendapat pelatihan khusus keterampilan berbicara bahasa asing seperti bahasa Inggris agar mereka memiliki daya saing yang tinggi di masa yang akan datang.
\end{abstract}

\begin{abstract}
Immersion teaching strategies and models are English learning models that are widely practiced in developed countries to accelerate the mastery of students as well as English students. To accelerate the ability to speak English, an easy generation, especially young people of the mosque as the next generation of the nation needs to get facilities and motivation from certain people such as mosque administrators and community leaders by bringing teachers or lecturers who are able to teach speaking skills using strategies and learning models that are right, interesting, interesting and liked by students. Teaching strategies and models used by English teachers or lecturers have a very important role to increase the interest and love of students who practice English language skills. Improving foreign language speaking skills such as English through formal activities has proven to be very far from expectations, and non-formal activities such as in course institutions also have not yielded satisfactory results in general because there are still very few students who can participate in this activity due to several factors, namely : economic factors, busyness with other subjects, and relatively low motivation to learn foreign languages.
\end{abstract}


The inhibiting factor was also experienced by mosque youth in Semangat Dalam Village, Alalak District, Barito Kuala Regency. Mosque youth need special training in foreign language skills such as English so they will have high competitiveness in the future.

\section{PENDAHULUAN}

Penguasaan berbagai macam keterampilan sangat diperlukan di era sekarang mengingat persaingan saat ini semakin ketat. Oleh karena itu setiap individu yang ingin bersaing perlu mempersiapkan diri dengan baik tak terkecuali para remaja masjid yang tersebar di seluruh penjuru negeri. Untuk bisa mencapai semua itu perlu keterlibatan pengurus masjid guna memfasilitasi serta memotivasi para remaja masjid agar bisa memiliki berbagai macam keterampilan, salah satu diantaranya yaitu keterampilan berbahasa Inggris. Menurut Rosaria \& Novika (2017) bahasa Inggris merupakan bahasa Internasional yang sangat diperlukan di era sekarang ini sehingga masyarakat dituntut untuk mampu menggunakannya secara pasif dan aktif. Namun sangat disayangkan meski keterampilan berbahasa Inggris memiliki peran penting dalam kehidupan namun masih banyak masyarakat tak terkecuali remaja mesjid yang merupakan siswa menengah atas dan atau bahkan mahasiswa baik yang ada diperkotaan terlebih yang di pedesaan belum memiliki kemampuan berkomunikasi dalam bahasa Inggris. Kegiatan peningkatan keterampilan berkomunikasi selama ini telah diadakan baik pada pendidikan formal maupun pendidikan non-formal. Upaya tersebut telah berlangsung sejak lama, namun sangat disayangkan penguasaan bahasa Inggris sebagai alat komunikasi belum terlihat fungsinya dengan baik. Para siswa ataupun mahasiswa meski telah mempelajari bahasa Inggris dalam jangka waktu yang lama, hasil yang dicapai masih sangat jauh dari esensi belajar bahasa yaitu mampu menggunakan bahasa tersebut untuk berkomunikasi. Beberapa faktor menjadi penyebab gagalnya mencapi target pembelajaran bahasa Inggris dua diantaranya yaitu metode dan media yang digunakan selama ini. Metode (strategi, model) merupakan sesuatu yang sangat krusial dalam kegiatan apapun termasuk dalam dunia pendidikan, demikian halnya dengan media pembelajaran. Media pembelajaran merupakan salah satu komponen pembelajaran yang mempunyai peranan penting dalam 
kegiatan belajar mengajar. Pemanfaatan media seharusnya merupakan bagian yang harus mendapat perhatian guru/fasilitator dalam setiap kegiatan pembelajaran. (Wagino, dkk 2015). Metode dan media yang digunakan selama ini kurang mampu menarik minat para siswa ataupun mahasiswa yang juga merupakan remaja masjid yang ada di Desa Semangat Dalam, Kecamatan Alalak Kabupaten Barito Kuala. Sehingga dengan demikian para remaja mesjid tersebut perlu mendapat pelatihan khusus keterampilan berbahasa Inggris agar mereka memiliki daya saing yang tinggi di tengah persaingan global saat ini dan dimasa yang akan datang.

Guru atau Dosen bahasa Inggris dapat mengakselerasi penguasaan keterampilan berbahasa asing para pembelajar melalui pengajaran formal atau non-formal dengan menggunakan strategi atau model pembelajaran yang tepat dan menyenangkan. Guru atau Dosen yang mengajarkan keterampilan berbicara dengan menggunakan strategi dan model pembelajaran yang tepat, atraktif dan menarik akan disenangi oleh para siswa. Strategi dan model pengajaran yang digunakan oleh para guru atau Dosen bahasa Inggris memiliki peran yang sangat penting untuk meningkatkan motivasi belajar sehingga para pembelajar memiliki keseriusan untuk berlatih yang pada akhirnya bisa mengantarkan mereka pada tujuan belajar bahasa yaitu mampu menggunakan bahasa tersebut untuk berkomunikasi dengan baik.

Berkenaan dengan program immersion yang didasarkan pada asumsi teoritis bahwa bahasa diperoleh melalui pengajaran di dalam kelas yang dapat dipahami (Swain, 1985). Ini sesuai dengan Krashen's Hypothesis yang menyatakan bahwa untuk diekspos ke lingkungan yang kaya akan kegiatan pengajaran yang mudah dipahami dan juga memungkinkan terjadinya foreign language acquisition yang mudah. Kebanyakan ahli teori akuisisi bahasa Inggris mendukung hipotesis pengajaran dalam beberapa bentuk. Stein (1999) menyampaikan hasil penelitiannya tentang pelajar imersion yang menunjukkan kompetensi berbahasa yang meningkat seperti penutur asli dalam pemahaman mendengarkan dan keterampilan membaca, pembelajar umumnya berada di belakang penutur asli dalam keterampilan bahasa produktif mereka seperti menulis dan berbicara. Menurut Harley \& Swain yang dikutif oleh Stein (1999) ada 
penekanan khusus pada peran model pengajaran yang dapat dipahami dalam proses akuisisi bahasa Inggris. Masukan yang dapat dipahami, selalu tersedia untuk pembelajar. Selain input yang dapat dipahami, penting juga untuk mempertimbangkan peran yang dimainkan dari output pembelajar itu sendiri (Swain, 1985). Output pembelajaran dapat dipertimbangkan dalam hal kemampuan lisan dan tertulis. Ini berpusat pada pertanyaan tentang bagaimana mendorong perkembangan kemahiran lisan pembelajar Imersion melalui diskusi. Program immersion yang dilaksanakan di di Negara lain diakui sukses oleh para ahli bahasa. Kesuksesan tersebut hendaknya menjadi referensi bagi para pengajar bahasa sekaligus menjadi dasar kebijakan bagi pemerintah agar program tersebut bisa diimplementasikan di sekolah-sekolah dan kampus-kampus yang ada di Indonesia.

\section{METODE PELAKSANAAN KEGIATAN}

Kegiatan pengabdian ini dilaksanakan dengan beberapa cara yaitu:

1. Memberikan tes awal untuk
mengetahui kemampuan awal
mahasiswa dan remaja mesjid Desa

Semangat Dalam, Kecamatan Alalak Kabupaten Barito Kuala dalam berbahasa Inggris

2. Memeriksa hasil tes awal mereka.

3. Menjelaskan kepada peserta tujuan kegiatan pengajaran pembelajaran bahasa Inggris beroriontasi pada komunikasi bahasa Inggris dengan menggunakan strategi immersion.

4. Memotivasi para peserta dengan menjelaskan mamfaat dari hasil kegiatan bila mengikuti seluruh rangkaian pengajaran bahasa Inggris menggunakan strategi Immersion.

5. Menjelaskan kaidah-kaidah bahasa Inggris secara umum untuk memudahkan peserta merangkai kalimat yang akan dia ungkapkan berdasar pada topik-topik menarik minat

6. Mencontohkan lansung kegiatan berbicara dibantu oleh mahasiswa senior yang mendampingi dosen selama kegiatan terhusus pada kegiatan bermain peran (role play) Seperti program: menjadi MC, menjadi reporter, pembaca berita, dan menjadi guru pelajaran agama dan guru pelajaran yang lain.

7. Pembelajaran bahasa Inggris dilaksanakan secara intensif salama 
seminggu dan peserta diharuskan bermalam di tempat kegiatan.

8. Memberikan tes akhir untuk mengetahui efektifitas strategi pembelajaran immersion yang digunakan dalam kurung waktu tertentu.

9. Memeriksa hasil tes akhir peserta pelatihan

\section{HASIL KEGIATAN DAN}

PEMBAHASAN

Tes awal yang dilaksanakan diikuti oleh semua peserta pelatihan, kemudian mereka mendapat pelatihan berkomunikasi bahasa Inggris selama satu minggu. Pelatihan tersebut menggunakan strategi immersion. Istilah immersion yang artinya membenamkan atau mencelupkan, menyerap atau terlibat. Metode pembelajaran yang melibatkan beberapa kelompok pembelajar yang bersama-sama belajar keterampilan berkomunikasi bahasa Inggris dan terus berlatih hingga menjadi keterampilan yang baik bagi mereka.

Pembelajaran berintegrasi sangat memungkinkan melalui strtegi immersion. Instruktur atau Dosen mengajarkan kepada peserta berkomunikasi dalam bahasa Inggris sambil memperkenalakan kepada mereka secara umum: vocabulary, fluency, grammar/structure. Pada Komponen Structure, Dosen menggunakan teknik To Be, To Do, To Have dan Modal Auxiliary. Kegiatan dengan strategi Immersion menyediakan topik-topik menarik minat dalam program diskusi, percakapan, dan pidato sehingga semua peserta merasa senang mengikuti seluruh rangkain acara.

Hari terakhir kegiatan pelatihan dengan menggunakan strategi Immersion. Peserta diberikan tes akhir berbicara bahasa Inggris. Nilai tes akhir lebih tinggi dari pada nilai tes awal. Dari data tersebut menunjukan bahwa strategi Immersion dalam belajar bahasa Inggris sangat efektif.
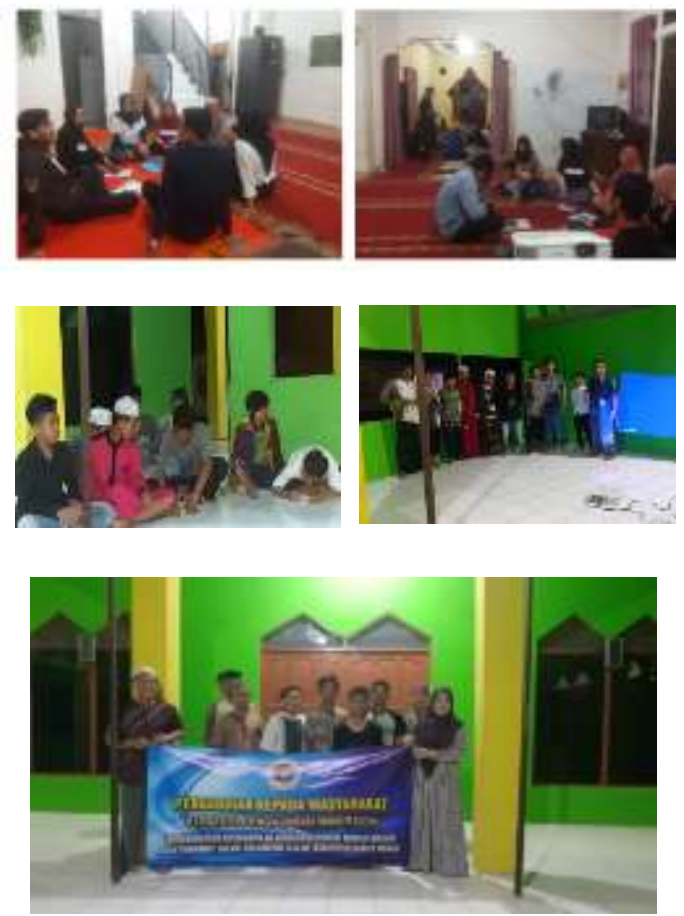
Hasil kegiatan pengabdian pada masyarakat dengan menggunakan strategi immersion adalah sebagai berikut:

1. Program peningkatan keterampilan berbahasa Inggris yang digagas oleh pengurus masjid Shuhaib Arrumy sejak lama telah terlaksana dan menunjukkan hasil yang menggembirakan.

2. Motivasi belajar bahasa Inggris remaja mesjid Shuhaib Ar Rumy semakin meningkat. Hal itu terlihat dari self-confidence mereka berbicara serta keseriusan menghafal kosa kata . Harapan pengurus masjid Shuhaib Ar Rumy untuk bekerjasama dengan pihak luar guna menjalanakan program peningkatan keterampalian berbahasa Inggris bagi para remaja masjid tersebut telah tercapai.

\section{KESIMPULAN}

Berdasarkan hasil pengamatan dan hasil tes kepada seluruh peserta kegiatan pengabdian pada masyarakat yang dilaksanakan pada bulan Pebruari 2020 di dua tempat yaitu di Mesjid Suaib Arumi dan di Komplek Persada Permai jalur 9 No. 14. RT 21,di Handil Bakti Desa Semangat Dalam,
Kecamatan Alalak Kabupaten Barito Kuala maka dapat disimpulkan bahwa:

a. Penggunaan strategi Immersion efektif dalam meningkatkan kompetensi berbahasa Inggris para peserta pelatihan dimana program peningkatan tersebut merupakan program yang telah digagas oleh pengurus masjid Shuhaib Ar Rumy sejak lama.

b. Penggunaan strategi Immersion efektif dalam meningkatkan minat atau motivasi para peserta untuk terus mengasah keterampilan mereka dalam berbahasa Inggris.

c. Penggunaan strategi Immersion efektif dalam meningkatkatkan kepercayaan diri semua peserta dalam berbahasa Inggris terutama pada program face to face dialoque (tetea-tete).

d. Penggunaan strategi Immersion sangat penting untuk di kembangkan, khususnya di Kalimantan Selatan dan Indonesia pada umumnya.

e. Tenaga pengajar bahasa Inggris disemua level pendidikan sebaiknya mempelajari serta mengimplementasikan strategi immersion ini di sekolah atau di wilayah kerja masing-masing 


\section{DAFTAR PUSTAKA}

Calderon, M., \& Slavin, R. E. (2001). Success for All in a two-way immersion school. In D. Christian \& F. Genesee (Eds.), Bilingual education (pp. 2740). Alexandria, VA: TESOL.

Cummins, J. (1998). Immersion education for the millennium: What we have learned from thirty years of research on second language immersion. In M. Childs \& R. M. Bostwick (Eds.), Learning through two languages: Research and practice (pp 34-58). Numazu, Japan: Katoh Gakuen.

Goldenberg, C. (1996). The education of language-minority students: Where are we, and where do we need to go? The Elementary School Journal, 96(3), 353-361.
Goldenberg, C. (Summer, 2008). Teaching English language learners: What the research does and does not say. American Educator, 33(2), 844.

Rosaria, D \& Novika, H. (2017). Bimbingan Belajar Bahasa Inggris Bagi Anak Usia Sekolah Dasar (6-12 Tahun) di Desa Semangat Dalam RT.31Handil Bakti. Jurnal Al-Ikhlas Volume 2 No. 2 April 2017 ISSN 24610992

Wagino., Alamsyah, N., Zainuddin. (2015). Pembuatan Media Pembelajaran Interaktif dengan Perangkat Lunak Ispring Presenter di SMAN 4 Banjarmasin. Jurnal Al-Ikhlas Volume 1 No. 1 Oktober 2015. ISSN2461-0992 